\title{
KNOWLEDGE MANAGEMENT AS THE BASE OF THE OPEN INNOVATION PROCESS
}

\section{VICTOR HUGO MEDINA GARCÍA, LAURA SOFIA ROMERO ALBARRACIN \& EDWIN RIVAS TRUJILLO \\ Universidad Distrital Francisco José de Caldas, Facultad de Ingeniería, Cra 7 No 40B-53, Bogotá, Colombia}

The purpose of this article is to analyze the relevance of Open Innovation, based on Knowledge Management carried out by SMES companies in Colombia. Likewise, it seeks to contextualize the reader and/or entrepreneur regarding new concepts and paradigms that imply the era of knowledge, such as Open Innovation.

To carry out this study, the Google Form tool was used, which allowed for a survey directed at the owners and / or managers of existing SMES in Colombia and researchers at the District University; this in order to demonstrate the knowledge on the part of those involved and the way to carry out aspects such as Knowledge Management, innovation and the articulation of these through external alliances, in the organization.

The surveyed actors consider that innovation is important and should impact socially. Most companies carry out some type of innovation in their organizations, however, much of them still do not know the term of Open Innovation and / or fear of opening organizational knowledge to an external entity. The entity that generates the most confidence among entrepreneurs to start with Open Innovation is the university

Manufacturing SMES can take advantage of the main features of Open Innovation that characterize companies in developed countries, integrating it with knowledge management, or developing AI processes applying the MEMFI methodological framework. In this way, it will strengthen its relationships and not only generating individual but collective benefits with which it will be allies, obtaining greater benefits and greater growth at the individual organizational level.
\end{abstract}

KEYWORDS: Open Innovation, Knowledge Management \& Smes.

Received: Oct 07, 2020; Accepted: Oct 27, 2020; Pbublished: Nov 11, 2020; Paper Id.: IJMPERDOCT202048

\section{INTRODUCTION}

This article takes up the concept of Knowledge Management developed through the different authors of the information and knowledge eras, they have discussed this concept without decoupling the importance and presence that Innovation represents within this process. whose central focus is the generation, transformation and dissemination of knowledge within the organization. Innovation initially seen as a result of an internal organizational process has been transformed and today it represents a paradigm for society, especially for companies and their entrepreneurs. Some of them are still unaware of the term open innovation, its implications, advantages and articulation with their Knowledge Management processes as generation of their competitive advantage.

The traditional KM model, in recent years of boom, has gained great ground in the different companies worldwide, in Colombia it is not the exception; However, the problem is that, like companies, information, external 
agents, society, everything is constantly changing and developing, and Knowledge Management models are also changing. Entrepreneurs are still stuck in the traditional, which results in Closed Innovation, and therefore does not allow it to exshop its organizational limits. This article shows the ignorance and even fears that different organizations face, regardless of their productive sector, of changing from the traditional model to new models that have emerged.

It is considered that one of the great fears on the part of entrepreneurs to start in Open Innovation is related to alliances with external agents to the organization, this is because Knowledge Management is carried out internally and its study was initially It based only on the information and processes of the company as such, just as the result of its implementation would be reflected as the generation of competitive advantage over its competitors, which would allow it to have a greater market and growth. For what would be seen as a loss of said advantage, opening its borders to extend it to other entities, be they business or academic.

\section{FRAMEWORK}

\subsection{Open Innovation}

In a world where globalization and technological advances have shown that systems have a high level of connection and interdependence with each other, Henry Chesbrough in 2003 mentions the term open innovation and defines it as the use of inflows and outflows of knowledge that streamline classical innovation, and which seeks to expand markets for external use of innovation(Álvarez, 2018).

This new approach is based on a different knowledge landscape, with a different logic about the sources and uses of ideas. Open innovation means that valuable ideas can come from inside or outside the company and can also go to the market from inside or outside the company. This approach places ideas and external paths to the market at the same level of importance as that reserved for internal ideas and paths during the era of Closed Innovation (Chesbrough, 2003).

The concept of open innovation has been studied by various authors, who vary in the definition of characteristics such as focus, application, formality or projection. Below is a graph that allows us to visualize the orientation of the different authors on the concept of open innovation:

\begin{tabular}{|c|c|c|c|c|c|c|c|}
\hline $\begin{array}{l}\stackrel{\sim}{\supset} \\
\text { 음 } \\
\text { 난 }\end{array}$ & $\begin{array}{l}\text { Towards the market } \\
\text { * Chesbrougth, } 2003 \\
\text { * Gassrnan \& Enkell, } \\
2004 \\
\text { * Dahlander, } 2005 \\
\text { * Hankel, } 2006 \\
\text { * Von Hippel \& von } \\
\text { Krogth, } 2006 \\
\text { Towards knowledge } \\
\text { * Laursen \& Salter, } \\
2006 \\
\text { * Van de vrrande ct al, } \\
2009 \\
\text { * Lichtenthaler et al, } \\
2009 \\
\text { * Waillin \& Von Krogh } \\
2010\end{array}$ & 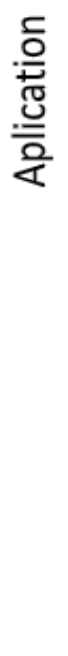 & $\begin{array}{l}\text { As Process } \\
\text { * Gassman \& Enkell, } \\
2004 \\
\text { * Waillin \& Von } \\
\text { Krogh, } 2010 \\
\text { As Practices } \\
\text { * Chesbrougth, } 2003 \\
\text { * Dahlander, } 2005 \\
\text { * Hankel, } 2006 \\
\text { * Von Hippel \& von } \\
\text { Krogth, } 2006 \\
\text { * Van de vrrande et } \\
\text { al, } 2009\end{array}$ & 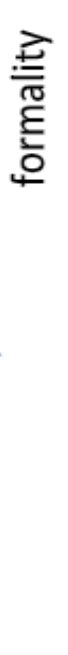 & $\begin{array}{l}\text { Has Model } \\
\text { * Gassman \& Enkell, } \\
2004 \\
\text { " Dahlander, } 2005 \\
\text { * Waillin \& Von } \\
\text { Krogh, } 2010 \\
\text { Doesn't Have } \\
\text { Model } \\
\text { "Chesbrougth, } 2003 \\
\text { * Laursen \& Salter, } \\
2006 \\
\text { " Hankel, } 2006 \\
\text { *Von Hippel \& } \\
\text { von Krogth, } 2006 \\
\text { * Van de vrrande et } \\
\text { al, } 2009\end{array}$ & $\begin{array}{l}\frac{c}{0} \\
\frac{0}{} \\
\frac{0}{0} \\
\frac{0}{2}\end{array}$ & $\begin{array}{l}\text { Endures } \\
\text { * Chesbrougth, } 2003 \\
\text { * Gassman \& Enkell, } \\
2004 \\
\text { * Dahlander, } 2005 \\
\text { * Laursen \& Salter, } \\
2006 \\
\text { * Hankel, } 2006 \\
\text { *Von Hippel \& } \\
\text { von Krogth, } 2006 \\
\text { * Van de vrrande et } \\
\text { al, } 2009 \\
\text { Will be absorved } \\
\text { by management } \\
\text { practices } \\
\text { *Von Hippel \& } \\
\text { von Krogth, } 2006 \\
\text { * Waillin \& Von } \\
\text { Krogh, } 2010\end{array}$ \\
\hline
\end{tabular}

Figure 1: Orientación Del Concepto De Innovación Abierta De Diversos Autores. Source: Jamett, Alvarado y Maturana (2017). 
According to Sobejano (2014) open innovation has 10 key points in the organization, which will be described below:

- Management commitment: it is essential to have such a commitment since management must be responsible for transmitting and raising awareness in the company about the importance of open innovation in its processes.

- Management participation: It is useless if only the information is transmitted, therefore, management participation is essential. Changes in the environment can cause crisis situations within the organization, it is the responsibility of the management to participate in the changes and manage them in the best possible way.

- Information is key: It is necessary to perform information management and leave the paradigm of traditional models that consider information as a possession.

- The objective is knowledge: Information management results in the creation of knowledge, which must be used by the organization in such a way that more and more knowledge is generated over time.

- As important as the organization of workers: Open innovation must also add value to workers. Furthermore, without them open innovation management would not be possible.

- Increased freedom: Open innovation brings with it an increase in freedom of decision and management by workers, as a consequence it is important to raise awareness among them about the high responsibility that must be handled in the decision-making process.

- Error or failure: It is part of management, and the company must be able to analyze it and make feedback processes that allow it to learn from it and generate continuous improvement processes.

- Redarquía: The network is a key concept, both internally and externally, it is essential to develop networks that strengthen the capacity to generate and transmit knowledge.

- Shared information: Internally improves the knowledge of the organization and externally increases the chances of relevance and finding allies for projects. Furthermore, it allows us to obtain other visions and interpretations of the shared information, enriching and increasing the possibilities of success.

- It is not a methodology: It is wrong to consider that it can be achieved through a checklist, which will work in all companies. It is rather an open management model that must be adapted to the specific needs and characteristics of each organization.

In countries such as Colombia, the context forces a paradigm shift to be generated that inserts the thought that competition can be a good ally and that with the help of collaborative and cooperative processes it is possible to increase market rates or sales revenue monthly.

The following table summarizes the identification and grouping of the main features or factors of open innovation of companies in developing and developed countries (the " $\mathrm{X}$ " means that companies in that type of country are characterized by having this trait). This table shows that companies and the environment in developed countries are characterized by having the different traits identified by the different scholars of open innovation considered as necessary traits for the success of these companies in the event of implementing this model of innovation. A different situation is evident for the case of companies and the environment in developing countries where only some features of the profile of competencies, internal capacities, knowledge management and use of TIC are present (Álvarez, 2017). 
Table 1: Open Innovation in Companies by Type of Country (Álvarez, 2017).

\begin{tabular}{|c|c|c|c|}
\hline \multicolumn{2}{|c|}{ Main Features of Open Innovation in Companies by Type of Country } & \multirow{2}{*}{$\begin{array}{c}\text { Developing } \\
\text { - }\end{array}$} & \multirow{2}{*}{$\frac{\text { Developed }}{\mathrm{X}}$} \\
\hline Factor & Main Features or Expressions of the Factor & & \\
\hline Strategy & Innovation as a company's competitive strategy & - & $\mathrm{X}$ \\
\hline \multirow{3}{*}{$\begin{array}{l}\text { Organizational } \\
\text { structures }\end{array}$} & Flexibility in the face of changes in the environment & - & $\mathrm{X}$ \\
\hline & Decentralization in decision making & - & $\mathrm{X}$ \\
\hline & Institutionalization of processes & - & $\mathrm{X}$ \\
\hline \multirow{2}{*}{ Competition Profile } & Interest in knowledge, trust and loyalty building & - & $\mathrm{X}$ \\
\hline & Commitment of managing directors and leaders & $\mathrm{X}$ & $\mathrm{X}$ \\
\hline \multirow{2}{*}{ Internal capabilities } & Mental flexibility, synergy between people, proactive ideas & - & $\mathrm{X}$ \\
\hline & Training, motivation, teamwork & $\mathrm{X}$ & - \\
\hline External capabilities & External relations, negotiation, loyalty and trust & - & $\mathrm{X}$ \\
\hline Licenses (PI) & Intellectual property licensing agreements & - & $\mathrm{X}$ \\
\hline \multirow[t]{2}{*}{$\begin{array}{l}\text { knowledge } \\
\text { management }\end{array}$} & Identify, exchange and appropriate knowledge & - & $\mathrm{X}$ \\
\hline & Capacities (absorption, transfer, etc.) & $\mathrm{X}$ & $\mathrm{X}$ \\
\hline \multirow{2}{*}{$\begin{array}{l}\text { Alliances and } \\
\text { collaboration } \\
\text { networks profile of } \\
\text { internal and external } \\
\text { knowledge }\end{array}$} & Exploration of clients, suppliers & $\mathrm{X}$ & $\mathrm{X}$ \\
\hline & $\begin{array}{l}\text { Exploitation, intermediaries, competitors, educational } \\
\text { institutions, research centers. }\end{array}$ & - & $\mathrm{X}$ \\
\hline \multirow{2}{*}{$\begin{array}{l}\text { Use of TIC and } \\
\text { technological } \\
\text { innovation systems }\end{array}$} & Flexibility, exploitation - depth & - & $\mathrm{X}$ \\
\hline & Exploration - breadth and disclosure & $\mathrm{X}$ & $\mathrm{X}$ \\
\hline \multirow{2}{*}{ TIC platform tools } & Data mining, simulation, prototyping, visual representation & - & $\mathrm{X}$ \\
\hline & Social networks, web & $\mathrm{X}$ & $\mathrm{X}$ \\
\hline \multirow{2}{*}{$\begin{array}{l}\text { Organizational } \\
\text { culture }\end{array}$} & $\begin{array}{l}\text { Interés por el desarrollo de talento humano, inteligencia } \\
\text { colectiva }\end{array}$ & - & $\mathrm{X}$ \\
\hline & $\begin{array}{l}\text { Interest in the development of human talent, collective } \\
\text { intelligence }\end{array}$ & - & $\mathrm{X}$ \\
\hline \multirow{2}{*}{ Government policies } & Regulatory institutions & - & $\mathrm{X}$ \\
\hline & Regulatory framework & - & $\mathrm{X}$ \\
\hline
\end{tabular}

According to Chesbrough (2003), open innovation thinking changes the role of the research function. Expand the role of internal researchers to include not only the generation of knowledge, but also the intermediation of knowledge. Previously, researchers simply added to the knowledge sitting in silos. Today, they are also in charge of moving knowledge in and out of silos. In this new role, knowledge located from the outside can be as useful as knowledge created from within, and should be similarly rewarded.

One implication of open innovation is that companies must increase the "metabolic rate" at which they access, digest and use knowledge. Companies cannot treat their knowledge as static; They should treat it as fundamentally dynamic. A company cannot inventory technological advances on the shelf, for the day they may prove valuable. Open innovation companies widely use licenses to create and expand markets for their technology. And the faster technology comes out of the lab, the sooner researchers will learn new ways to apply, leverage, and integrate that technology into new offerings (Chesbrough, 2003).

\section{$2.2 \quad$ Knowledgemanagement}

Between the 60's and 70's there were signs and even experts studying evolutionary phenomena in society, given that a new era was coming. Industrialization was no longer the driving force of society, but information, knowledge and learning. Machlup, McLuhan, Tourain and Bell (2016) are some of the experts who first named terms related to what they called the 
new thrusters of society. On the other hand, Porat in 1967, he affirmed that the information services and goods reached $46 \%$ of the GDP of the United States (Rubén, 1990); as early as 1974, he called the information economy as a new field of productive activity and related it directly to technological development (Alfonso, 2016).

The role of information and communications in society, and the importance that it is increasingly acquiring in it, have generated concern among experts to dig further into their study. Between the following two decades, the term Information Society is consolidated and expanded, Nasbitt lays the foundations (Alfonso, 2016), and on the other hand, Nora and Minc emphasize the scope of information processes, such as computing and the telephone; giving rise to the term of telematics (Crovi, 2005).

And of course it is inevitable to speak of this new society, economy and / or era, without mentioning the importance of knowledge in it. With the passage of time, more and more new information and communication technologies are developed and consolidated, facilitating access to this essential asset for organizations; each time from a greater number of sources and at a higher speed. Even these technologies allow the generation of own databases that increase the information gathered. As Sánchez mentions, "the greater the amount of information generated by a society, the greater the need to convert it into knowledge." However, this is one area in which technology still falls short; knowledge is the information processed by the human mind that includes experiences, values and contexts, difficult to structure by machines (Medina, 2019).

The most important characteristic of the information age is that its central focus, information and knowledge, are used as an economic resource, therefore, it reflects a competitive advantage in products and / or services, efficiency, and of course, increased innovation capacity in an organization (Alfonso, 2016). And it is there where the knowledge society is discussed, and the need arises to manage knowledge through a process of data, learning and, finally, mental creation, generating distinctive competence (Medina, 2019).

Finally, it is concluded that what characterizes the current technological revolution is not the central character of knowledge and information, but the application of that knowledge and information to knowledge generation and information processing / communication devices, in a circle of cumulative feedback between innovation and its uses (CEN, 2004). The challenge from the end of the 90's to even today has been to establish processes and activities to enhance and increase knowledge in organizations, the latter evidenced the importance of information management for the process of creating knowledge at both the collective and individual level, which is why greater attention has been paid to collecting the information itself and especially the flows, so that the correct information reaches where it is necessary and therefore there is interconnectivity between the different units that they form the organization. All this leads to "continually innovate in search of sustainable competitive advantage as an expression of value" (Castells, 2003). And in reality this is the way in which professionals, and experts have defined Knowledge Management.

\subsection{Open Innovation and Knowledge Management}

As mentioned, Knowledge Management begins at the internal level of the organization, that is, the organizations took part in generating knowledge and information from the experiences within it at a collective and individual level, and also to transmit this knowledge to other levels, employees and / or dependencies, taking care of exposure to external agents. It should be noted that these planned and directed actions are responsible for generating innovative capacity in the members. Knowledge management, evidencing a competitive advantage, made organizations show suspicion in aspects such as 
processes, strategies, methodologies, culture, information and communication technologies, among others. In short, this closed innovation model defends, on the one hand, that the only strategic knowledge is that developed from internal sources and, on the other hand, that the materialization of economic results is achieved exclusively through the incorporation of such knowledge on the products in your portfolio (González, 2011).

Departing from the traditional model of knowledge management, and of course from closed innovation, open innovation proposes a new paradigm regarding interaction with third parties, dealing with a technological and knowledge transfer in a double, internal direction. and external (González, 2011). Alliances and constant communication with others will be complementary and will become part of the knowledge generation processes, being reflected in the new organizational models, the integration of open Innovation in the way of managing knowledge and information.

If innovation was driven and influenced by the knowledge of that organization, now having different sources, this relationship will be strengthened and will be directly responsible for the good business results. This time not only generating individual but collective benefits with which they will be the allies, obtaining greater benefits and greater growth at the individual organizational level. As far as open innovation is concerned, the only agents are not only similar organizations or potential competitors, there are other types of actors who have great ideas and who must start to interact more and more, such as universities, centers Research, suppliers, distributors, companies of course customers (González, 2019).

\section{METHODOLOGY}

A survey was conducted of 25 manufacturing PIMES companies in Bogotá, classified according to CIIU code Section C, Table 2 shows the economic activity reported by the surveyed companies. In order to diagnose the relevant factors in the innovation practices carried out in their organizations. $61.5 \%$ of the surveyed companies are small companies, that is, they have between 11 and 50 workers and $38.5 \%$ are medium-sized companies, that is, they have between 51 and 250 workers.

Likewise, a survey was conducted of 50 teachers and researchers belonging to the Francisco José de Caldas District University in order to validate their experiences, knowledge and willingness to develop open innovation processes.

Table 2: Economic Activity

\begin{tabular}{|l|l|}
\hline CIIU & Economic Activity \\
\hline C10 & Manufacture of food products \\
\hline C13 & Manufacture of textile products \\
\hline C20 & Manufacture of chemical substances and products \\
\hline C21 & Manufacture of pharmaceuticals, medicinal chemicals and botanicals for pharmaceutical use \\
\hline C22 & Manufacture of rubber and plastic products \\
\hline C25 & Manufacture of fabricated metal products, except machinery and equipment \\
\hline C26 & Manufacture of computer, electronic and optical products \\
\hline C27 & Manufacture of electrical appliances and equipment \\
\hline C28 & Manufacture of machinery and equipment n.c.p \\
\hline C30 & Manufacture of other types of transport equipment \\
\hline C32 & Other manufacturing industries \\
\hline C33 & Installation, maintenance and specialized repair of machinery and equipment \\
\hline
\end{tabular}

The teachers and researchers surveyed belong to different faculties of the University. Below is a graph that shows the proportions of respondents depending on the faculties with which they are associated: 


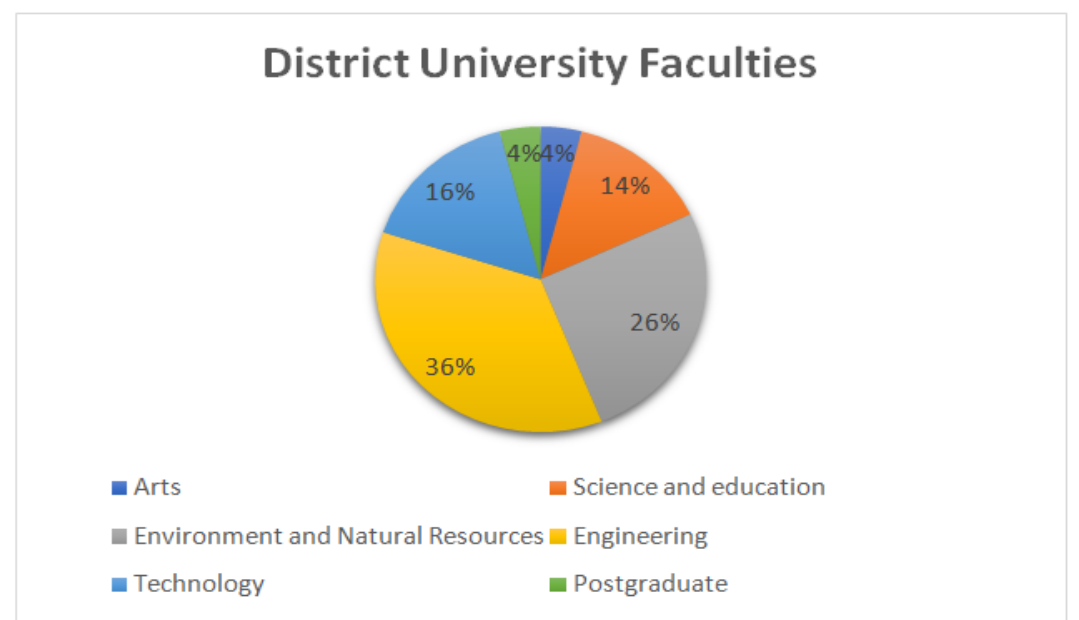

Figura 3: Distribución De Los Docentes e Investigadores Encuestados Por Facultad

Subsequently, the responses obtained are analyzed and the factors related to knowledge management are discussed.

\section{ANALYSIS OF RESULTS}

$88 \%$ of the companies surveyed consider innovation important in their organizations and more than half of the teachers and researchers consider that innovation at the University takes into account that its results have a broad impact in our country. This means that the actors surveyed for analysis in this study agree that innovation is important and must impact socially.

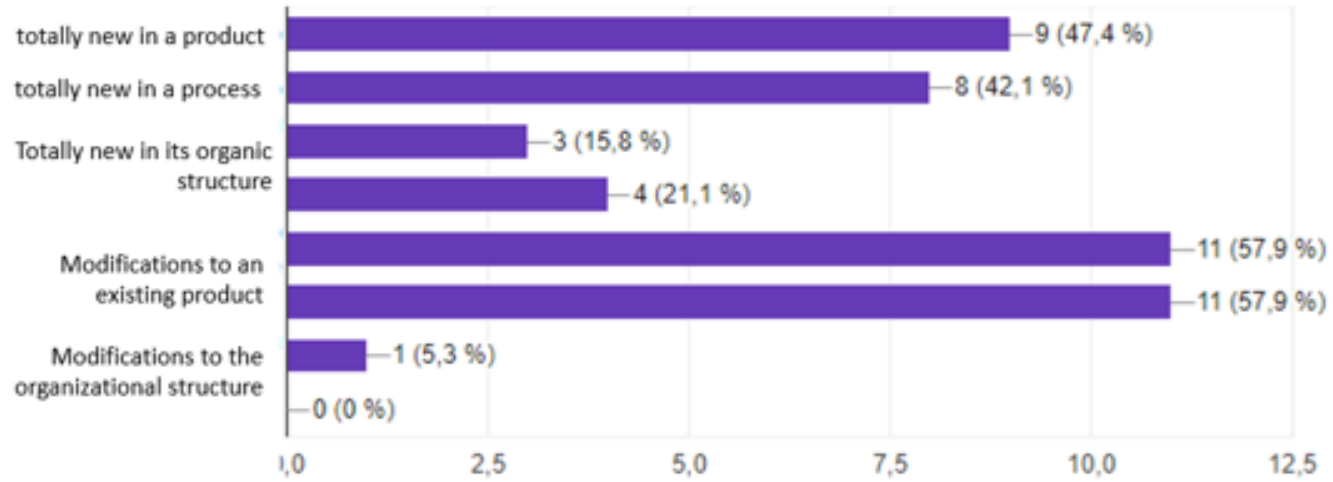

Figure 4: Types of Innovation Carried Out by the Companies Surveyed. Source: Authors.

Companies refer to the main reason why they have not introduced any innovation in their company are organizational reasons. In addition, $64 \%$ state that they collect and analyze data to carry out innovations and 52\% evaluate and generate feedback processes based on innovations developed in order to implement improvements.

Only 9 of the 25 companies surveyed responded that they had some kind of willingness to work with other actors on their current innovations. The other companies responded negatively due to issues of intellectual property, cumbersome steps, confidentiality, security policies, and organizational structure for said processes, among others. They express on average, from a rating between 1 and 10, of 4.64 the risk assumed by the organization when developing innovations in conjunction with other organizations.

To the question "Are you willing to change the way in which the people in your organization work, in order to 
improve productivity through collaborative work with other entities?" $96 \%$ of the companies answered affirmatively. On the other hand, on the implications that companies consider that brings together working with other entities are: loss of knowledge, agility in innovation, improvement in productivity, generation of knowledge and results with more complete and comprehensive solutions.

The university is considered by $84 \%$ of the companies surveyed, the entity with which it is willing to work in the development of innovation activities. $45 \%$ of teachers and researchers consider that the university encourages the exchange of ideas, knowledge and technologies among academics, the productive sector and the social sector; $43 \%$ consider that the university has mechanisms to obtain and transfer knowledge between academics and other sectors on an occasional basis. And almost two thirds of the respondents are interested in sharing knowledge with other sectors or institutions.

The vast majority of the teachers and researchers surveyed consider that the university should support innovation in different productive and social sectors with their knowledge. Almost two thirds of the teachers and researchers surveyed are unaware of the existence of joint or cross intellectual property. Opinion is divided on whether the university has platforms or portals that allow the dissemination of the knowledge created, the result of the academic, research and extension. $47.7 \%$ consider that it is easy to share information, knowledge and technologies with other institutions to develop projects. Finally, $90.9 \%$ of those surveyed consider the existence of research and innovation networks created by the university to be important.

\section{DISCUSSION OF RESULTS AND SOLUTIONS}

Knowledge management, evidencing a competitive advantage, made organizations show suspicion in aspects such as processes, strategies, methodologies, culture, information and communication technologies, among others (González, 2019). In this same order of ideas, a widespread concern on the part of the two surveyed actors about knowledge management described in words such as, intellectual property, cumbersome efforts, confidentiality, security policies regarding knowledge and ideas generated, organizational structure and / or mechanisms for carrying out said processes , among other. This makes evident the need to design tools that appease these concerns because, as Davenport says, knowledge is the information processed by the human mind that includes experiences, values and contexts, difficult to structure by machines.

The most important characteristic of the information age is that its central focus, information and knowledge, are used as an economic resource, therefore, it reflects a competitive advantage in products and / or services, efficiency, and of course, increased innovation capacity in an organization (Alfonso, 2016). The foregoing is evidenced in the interest expressed by both companies and the university in the development of joint open innovation processes. Companies are willing to change the way their organizations work in order to improve productivity, which in the long run turns into profitability through collaborative work with other entities and, on the other hand, $75 \%$ of teachers and researchers Respondents consider it pertinent that the university commercialize the results of the research or innovations developed.

Departing from the traditional model of knowledge management, and of course from closed innovation, open innovation poses a new paradigm regarding interaction with third parties, dealing with a technological and knowledge transfer in a double direction, internal and external. [eleven]. In the case of the respondents, a broad willingness is interpreted by both the business sector and members of the university to participate in open innovation, knowledge transfers and collaborative research processes. 
$47.7 \%$ of the teachers and researchers surveyed consider that it is easy to share information, knowledge and technologies with other institutions for the development of projects. This makes us think that just as the company emphasizes the difficulty of having an adequate organizational structure, the university also recognizes that sharing information, knowledge and technologies is not in fact an easy process. A fundamental flaw is detected, regarding the methodology or facilitating framework of open innovation processes between company-university.

As a solution proposal, the Evolutionary Phased Methodological Framework for Innovation (MEMFI) is proposed, which is shown in Figure 5.

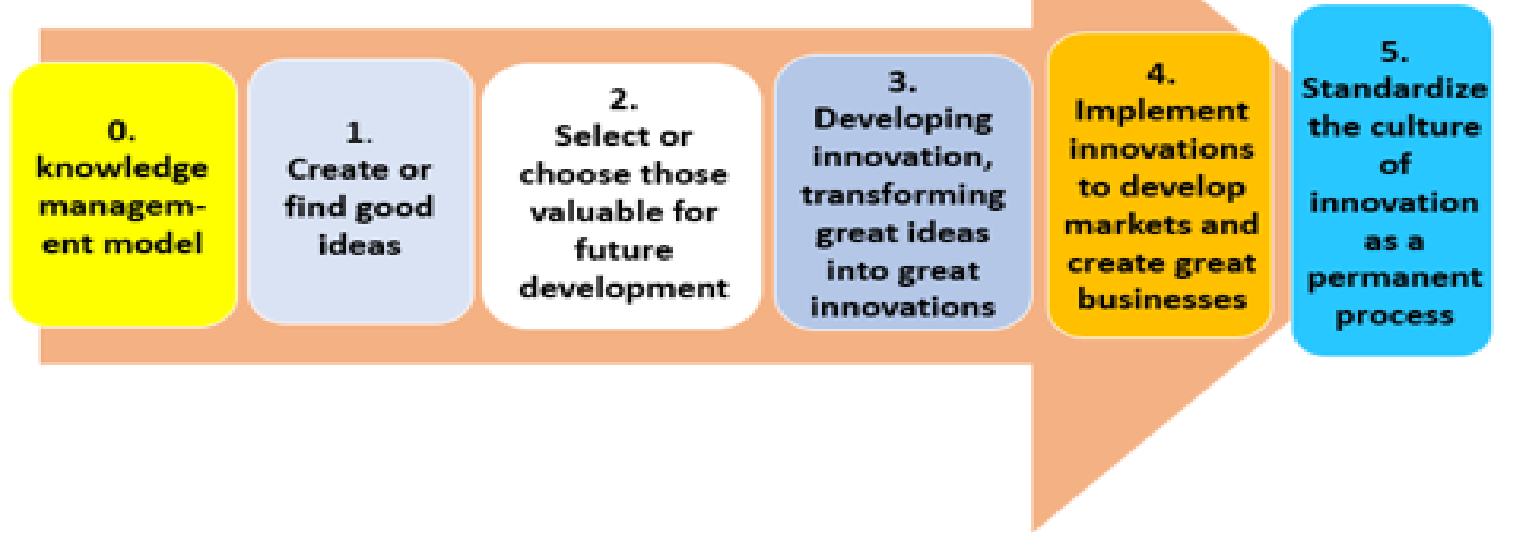

Figure 5: Integration Model between Knowledge Management and Open Innovation MENFI (Medina, 2012).

The MEMFI model initially proposes the creation of a knowledge management model adapted to the parties involved, after which the creation and selection of ideas is proposed, to develop and implement innovations that generate value for organizations, additionally it proposes standardization of an innovative culture, that is, it offers the possibility of continuing to work on the development of innovation processes among the actors. This model is proposed as a methodological facilitator in open innovation processes between the company-university, all the phases that comprise it must be developed according to the contexts of each of the participating actors.

Said model should not be understood as a straitjacket, it should be viewed as a methodological framework, which can iterate during its development, that is, any phase can be repeated or executed according to the parties' convenience. It is also fully open to the inclusion of additional phases that complement the proposed framework.

The model is proposed as a facilitator, but it should be noted that there are still many factors of high concern among the parties to be resolved, especially aspects related to intellectual property, confidentiality, marketing agreements, among others. Themes that remain as a proposal for future research and / or as a development task among the developers of open innovation processes.

Manufacturing SMES in Bogotá can take advantage of the main features of Open Innovation that characterize companies in developed countries, such as: commitment of managing directors and leaders; training-citation, motivation, teamwork; capacities (absorption, transfer, etc.); exploration of customers, suppliers and management of social networks, web. When developing open innovation processes applying the MEMFI methodological framework, it is hypothesized that SMES can acquire features of open innovation such as: implementing innovation as a competitive strategy of the company, 
increasing interest in knowledge, building trust and loyalty; mental flexibility, synergy between people, proactivity of ideas and development of human talent with collective intelligence; generation of external relations, negotiation, loyalty and trust; definition of intellectual property licensing agreements; increase in processes of exchange and appropriation of knowledge; use of intermediaries, competitors, educational institutions, research centers(Álvarez, 2017).

\section{REFERENCIAS}

1. E. Álvarez, M. Álvarez. Estrategias y prácticas de la innovación abierta en el rendimiento empresarial: Una revisión y análisis Bibliométrico.(2018). Magazine SCIELO. Mexico. [Online] Available in: http://www.scielo.org.mx/scielo.php?script=sci_arttext\&pid=S2448-76782018000100004

2. Chesbrough, H.W. Open Innovation: The New Imperative for Creating and Profiting from Technology. (2003). Harvard Business School Press, Boston, USA.

3. Jamett, L. Alvarado,S. Maturana. Análisis al estado del arte de la innovación abierta: Implicaciones prácticas en la ingeniería. (2017). Magazine SCIELO. Chile. Pags. 65-76. [Online] Available in: https://scielo.conicyt.cl/scielo.php?script=sci_arttext\&pid=S0718-50732017000200006

4. E. Álvarez, C. Bernal. Modelo de Innovación Abierta: Énfasis en el Potencial Humano. Magazine Información Tecnológica. (2017). México. [Online] Available in: https://scielo.conicyt.cl/pdf/infotec/v28n1/art07.pdf

5. Machlup, McLuhan, Tourain and Bell. (2016). Internet Studies: Past, Present and Future Directions. Routledge Tayler \& Francis Group. London.

6. B. Rubén. En la era de la información: información, tecnología y estudio del comportamiento.(1990). Magazine Documentación De Las Ciencias De La Información. USApágs.13-53. [Online] Available in: https://revistas.ucm.es/index.php/DCIN/article/view/DCIN9090110053A

7. Alfonso. La Sociedad de la Información, Sociedad del Conocimiento y Sociedad del Aprendizaje. Referentes en torno a su formación. (2016). Bibliotecas Anuales de investigación Reflexiones. Volume No 2. Cuba. Págs. 235-243.

8. D. Crovi. La sociedad de la información una mirada desde la comunicación.(2005). Magazine science. Págs. 23-37. [Online] Availble in: https://www.revistaciencia.amc.edu.mx/images/revista/56_4/la_sociedad.pdf

9. V. Medina and D. Castañeda. Innovation Model: Evolutive methodological framework, on phases to innovation MENFI.(2011). KMO2011 - 6th International Knowledge Management Organization Conference. Tokyo.

10. CEN -European Guide to good Practice in Knowledge Management. (2004). Chapter 5. Brussels.

11. M. Castells. La era de la información: economía, sociedad y cultura. (2003). Volume1. Alianza Editorial. Spain.

12. R. González, F. García. Innovación abierta: un modelo preliminar desde la gestión del conocimiento. (2011).Revista Intangible Capital. Volumen No 7. Spain. [Online] Available in: https://www.researchgate.net/publication/277129475_Innovacion_abierta_un_modelo_preliminar_desde_la_gestion

13. J. González, L. Álvarez. Gestión de Conocimiento e Innovación Abierta: hacia la conformación de un modelo teórico relacional. (2019). Revista Venezolana de Gerencia, volumen 24. Colombia. [Online] Available in: https://www.redalyc.org/jatsRepo/290/29062051013/html/index.html

14. J. Sobejano. 10 puntos clave de la Innovación Abierta.(2019). Innodriven is a brand lead by 3Vectores (a Certified B Corporation) \& Global Partners.[Online Available in: https://innodriven.com/es/10-puntos-clave-de-la-innovacion-abierta/ 